\title{
Intrinsic effects of gold nanoparticles on proliferation and invasion activity in SGC-7901 cells
}

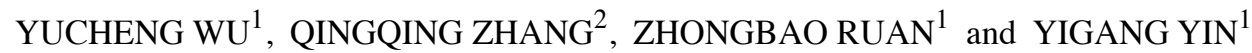 \\ Departments of ${ }^{1}$ Cardiology and ${ }^{2}$ Endocrinology, Taizhou People's Hospital, Taizhou, Jiangsu 225300, P.R. China
}

Received October 4, 2015; Accepted November 8, 2015

DOI: 10.3892/or.2015.4474

\begin{abstract}
Although biomedical applications of functionalized nanoparticles have taken significant strides, biological characterization of unmodified nanoparticles remains unclear. In the present study, we investigated the cell viability and invasion activity of gastric cancer cells after treatment with gold nanoparticles. The growth of SGC-7901 cells was inhibited significantly after treatment with 5-nm gold nanoparticles, and the cell invasion decreased markedly. These effects were not seen by different size gold nanoparticles (10, 20 and $40 \mathrm{~nm})$. The attenuated invasion activity may be associated with the decreased expression of matrix metalloproteinase 9 and intercellular adhesion molecule-1. These data indicated that the response of SGC-7901 cells to gold nanoparticles was strongly associated with their unique size-dependent physiochemical properties. Therefore, we provided new evidence for the effect of gold nanoparticles on gastric cancer cell proliferation and invasion in vitro, making a contribution to the application of gold nanoparticles to novel therapies in gastric cancer.
\end{abstract}

\section{Introduction}

Gold nanoparticles (Au-NPs) have attracted wide attention in various biomedical applications and also have appealing potential to positively impact the health care system (1-3). Not only can Au-NPs be made as scaffolds for more and more potent cancer drug delivery but they can also act as intrinsic antineoplastic agents (4-6). Arvizo et al (7) have demonstrated that unmodified Au-NPs could inhibit the proliferation of cancer cells by abrogating MAPK-signaling.

Although the application of Au-NPs have been studied in detail, response of biological systems to the nanoparticles remain to be elucidated. In addition, exploration of the sizedependent physicochemical properties of the Au-NPs also resulted in controversial conclusions. Arvizo et al (8) showed

Correspondence to: Dr Yucheng Wu, Department of Cardiology, Taizhou People's Hospital, 210 Yingchun Road, Taizhou, Jiangsu 225300, P.R. China

E-mail: 18061986120@189.cn

Key words: proliferation, invasion, SGC-7901, gold nanoparticles that nanoparticle size plays a very important role in the therapeutic effect. Small Au-NPs (diameter $<2 \mathrm{~nm}$ ) could penetrate the cell nucleus and be highly toxic (9). However, Connor et al (10) demonstrated that Au-NPs with a size of $18 \mathrm{~nm}$ could also be endocytosed by cells, but showing no inherently toxicity to human cells. Due to the contradictory results of the previous investigations, the effect of Au-NPs on cells requires more study.

The most pivotal pathologic feature of cancer cells is generally thought as invasion and metastasis (11). The process of cell invasion and metastasis begins with cell proliferation, then dissociate from the primary lesions and migrate in the blood or lymph stream leading to adhesion in a secondary organ (12). Despite increased progression in surgery, chemotherapy and radiotherapy, recurrence is almost inescapable in case of an aggressive metastatic spread $(13,14)$. Previous studies have demonstrated that intercellular adhesion molecule-1 (ICAM-1) and matrix metalloproteinase 9 (MMP9) play an important role in cancer cell adhesion, invasion and migration $(15,16)$. These proteins have been used as prognostic biomarkers for gastric cancer progression (17).

This study concentrated on effects of Au-NPs on cell proliferation, invasion and protein expression. Besides, we chose to investigate these effects on the human gastric cancer cell line (SGC-7901), which is a high epidemic tumor in China (18). Moreover, to explore the value of particle size in biomedical application, four different sizes (5, 10, 20 and $40 \mathrm{~nm}$ ) were chosen for detailed analysis of this system. Therefore, the goal of the present study was to explore the effect of Au-NPs on proliferation and invasion in SGC-7901 cells, which may promote the application of Au-NPs in gastric cancer therapy.

\section{Materials and methods}

Syntheses of Au-NPs. Syntheses of 5-nm and 10-nm Au-NPs were conducted using a reducing agent (tannic acid) and a stabilizing agent (citrate) (19). For each synthesis, two original solutions were prepared: a) $1 \mathrm{ml}$ of $1 \%(\mathrm{w} / \mathrm{v}) \mathrm{HAuCl}_{4}$ solution added with $79 \mathrm{ml}$ of water; and b) a mixed solution consisting of $4 \mathrm{ml}$ of $1 \%(\mathrm{w} / \mathrm{v})$ citrate solution, $0.7 \mathrm{ml}$ or $0.1 \mathrm{ml}$ of $1 \%$ tannic acid and water $(20 \mathrm{ml}$ in total). The solutions were heated to $60^{\circ} \mathrm{C}$ and then solution $\mathrm{b}$ was poured to solution a with constant stirring. The finished Au-NPs were cooled to room temperature (RT) before use. 
Syntheses of 20- and 40-nm Au-NPs were made by the classic citrate reduction method (20). For each synthesis, $100 \mathrm{ml}$ of $0.01 \% \mathrm{HAuCl}_{4}$ solution was heated to boiling. Citrate solution $(1 \%)$ (4.5 or $1.0 \mathrm{ml})$ were added and then heated to boiling until the color changed. The solution was cooled to RT for subsequent experiments.

Transmission electron microscopy (TEM; JEM-2100EX; JEOL, Tokyo, Japan) was used to determine the morphology of Au-NPs. Ultraviolet-visible (UV-Vis) spectra was obtained by a spectrophotometer (300-1100 nm; Shimadzu Corp., Kyoto, Japan).

Cell culture. The human gastric cancer cell line, SGC-7901 cells (Chinese Academy of Sciences), were cultured in Dulbecco's modified Eagle's medium (DMEM) with fetal bovine serum (FBS; Invitrogen, Carlsbad, CA, USA) at $37^{\circ} \mathrm{C}$ with $5 \% \mathrm{CO}_{2}$. Cells were co-cultured with $\mathrm{Au}-\mathrm{NPs}$ solution $(50 \mu \mathrm{g} / \mathrm{ml})$ for $24 \mathrm{~h}$. Cells at the logarithmic growth phase were collected by EDTA (Invitrogen) detachment for other uses.

Uptake and TEM studies. The uptake of Au-NPs by cells was observed by TEM. Before exposure to the Au-NPs, the SGC-7901 cells with a concentration of $1 \times 10^{6}$ cells/dish (100-mm; Corning Incorporated, Corning, NY, USA) were incubated for $24 \mathrm{~h}$. After co-incubation with Au-NPs for $24 \mathrm{~h}$, the cells were fixed for TEM analysis. Firstly, cells were fixed in $1 \%$ osmium tetroxide for $2 \mathrm{~h}$, and then cells were dehydrated with ethanol of increasing concentration for $15 \mathrm{~min}$ each. The cells were then embedded at $80^{\circ} \mathrm{C}$ by resin in propylene oxide polymerise. Lastly, the samples in ultrathin sections were analyzed by TEM.

Cell viability assay. SGC-7901 cells, seeded in 96-well plates (2,000 cells/well) overnight, were treated with different Au-NPs. After $24 \mathrm{~h}$, each well was added with the reagent (Cell Counting kit-8; Nanjing KeyGen Biotech. Inc., Jiangsu, China) and co-incubated for 1, 2, 3 or $4 \mathrm{~h}$. A microculture plate reader (Bio-Rad Laboratories, Hercules, CA, USA) was used to test the absorbance at $450 \mathrm{~nm}$ and the cell viability was calculated as a percentage of the control. This assay was conducted in triplicate and the experiment was repeated thrice.

Invasion assay. For this assay, an insert with the pore size of $8.0 \mu \mathrm{m}$, pre-coated with Matrigel (BD Biosciences, San Jose, CA, USA), was put on the culture plate. After treated with $\mathrm{Au}-\mathrm{NPs}$ solution for $24 \mathrm{~h}$, the harvested cells $\left(2.5 \times 10^{5}\right.$ cells $)$ were seeded in the upper of the insert with $200 \mu 1$ DMEM containing $0.2 \%$ bovine serum albumin. Then, $750 \mu \mathrm{l}$ DMEM supplemented with $5 \%$ FBS was added to the bottom of the well for $24 \mathrm{~h}$ in the incubator.

The cells in the upper and bottom of the chamber were fixed with $4 \%$ formaldehyde by replacing the culture medium. After $15 \mathrm{~min}$, the chambers were washed with PBS and stained with $0.1 \%$ crystal violet for $10 \mathrm{~min}$. After washing the chambers five times with $\mathrm{dH}_{2} \mathrm{O}$, the cells left on the top of membrane were removed by $\mathrm{Q}$-tips. The cells that remained were those that had invaded through the membrane.

The invasion cells were also quantified using the $\mathrm{QCM}^{\mathrm{TM}}$ 24-well Cell Invasion Fluorometric assay (Millipore). This assay provides an efficient system for quantitative detection of cell invasion through a basement membrane model. SGC-7901 cells, treated with or without Au-NPs, were cultured in complete medium for $24 \mathrm{~h}$. Then, cells were harvested and seeded $\left(2.5 \times 10^{5}\right.$ cells $)$ in a plate chamber with $250 \mu \mathrm{l}$ serumfree medium. DMEM containing $10 \%$ FBS was used as chemoattractant to add to the lower chamber. After $24 \mathrm{~h}$, cells on the upper membrane were removed. Next, the inserts were put into a new well added with cell detachment solution at $37^{\circ} \mathrm{C}$ for half an hour. After removing the inserts, the detached cells were split and stained with lysis buffer/dye solution (Millipore) for $15 \mathrm{~min}$. Lastly, relative fluorescence unit (RFU) values of the mixtures were recorded using a fluorescence plate reader (Synergy HT) at 480/520 nm.

Quantitative reverse transcription polymerase chain reaction ( $q R T-P C R)$ assays. Total RNA was isolated from SGC-7901 cells in each group using TRIzol reagent (Invitrogen-Life Technologies). Reverse transcription into cDNA was conducted with $1 \mu \mathrm{g}$ of total RNA, and then qRT-PCR was performed with SYBR-Green Mix (ABI7300 Real-Time PCR system). The primer sequences were as follows: glyceraldehyde 3-phosphate dehydrogenase (GAPDH), forward, GGAGCCAAACG GGTCATCATCTC and reverse, GAGGGGCCATCCACAGT CTTCT; MMP9, forward, GGCTACGTGACCTATGACATC CT and reverse, TCCTCCCTTTCCTCCAGAACA; ICAM-1, forward, ACACTAGGCCACGCATCTGAT and reverse, AGC ATACCCAATAGGCAGCAA. PCR was performed at $95^{\circ} \mathrm{C}$ for $30 \mathrm{sec}$, at $60^{\circ} \mathrm{C}$ for $30 \mathrm{sec}$, and at $70^{\circ} \mathrm{C}$ for $60 \mathrm{sec}$ for 35 cycles. The relative abundance of mRNA was evaluated by comparative $\mathrm{Ct}$ method. The experiment was conducted three times independently.

Protein quantitative assays. Protein expression of MMP9 and ICAM-1 in the cell lysate was detected by an MMP/ICAM-1 Panel magnetic bead kit (Luminex technology; EMD Millipore, Billerica, MA, USA). Firstly, MMP9/ICAM-1 capture antibodies and detection antibodies were combined with Luminex beads or biotin, respectively. MILLIPLEX MAP lysis buffer and cell assay buffer (Millipore) were used to lyse cells or dilute cells, respectively. The capture antibody beads, diluted with $25 \mu \mathrm{l}$ of cell assay buffer, were transferred to a magnetic plate (96-wells; Millipore). Next, $25 \mu \mathrm{l}$ of the diluted cell lysate was added to the magnetic plate. After incubation for $2 \mathrm{~h}$ at RT with shaking, beads were washed twice using wash buffer. Then, $25 \mu \mathrm{l}$ of detection antibodies was added into the magnetic plate. After incubation for $1 \mathrm{~h}$ at RT with shaking, $25 \mu \mathrm{l}$ of MILLIPLEX MAP streptavidin-phycoerythrin (Millipore) was supplemented for 30-min incubation at RT with shaking. Lastly, the signal data was recorded using a Luminex FLEXMAP 3D ${ }^{\mathrm{TM}}$.

Statistical analysis. All statistical analyses in the present study were carried out with the GraphPad Prism software version 5.0 (GraphPad Software, Inc., San Diego, CA, USA). The data are reported as mean \pm standard deviation (SD). Statistical comparisons were performed by one-way analysis of variance (ANOVA), and the Dunnett's t-test was conducted for comparison with the control group. P-value $<0.05$ was considered as significant statistical difference. 


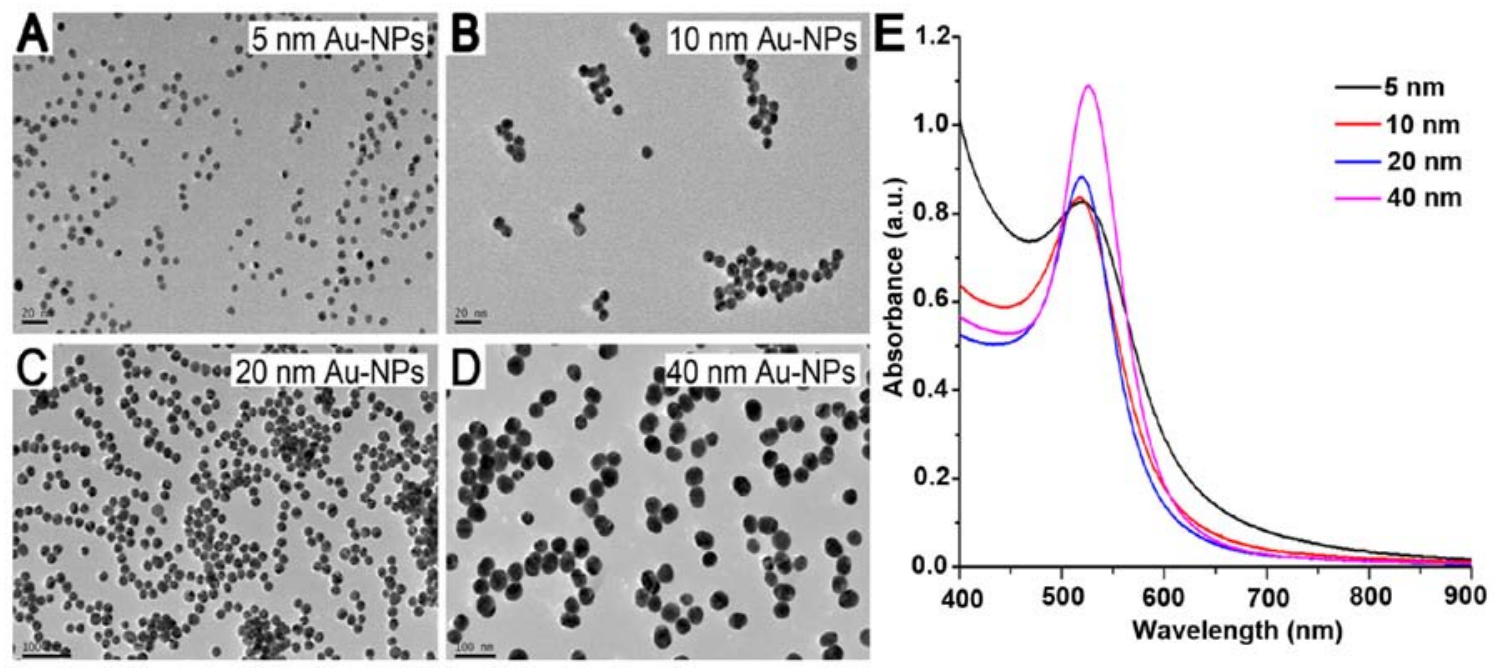

Figure 1. Characterization of the differently sized Au-NPs. Transmission electron microscopy (TEM) images of Au-NPs with diameters of (A) $5 \mathrm{~nm}$, (B) $10 \mathrm{~nm}$, (C) $20 \mathrm{~nm}$, or (D) $40 \mathrm{~nm}$. Scale bars, 20 and $100 \mathrm{~nm}$ (as marked). (E) UV-vis spectra of Au-NPs with diameters 5, 10, 20 and $40 \mathrm{~nm}$.


Figure 2. Transmission electron microscopy (TEM) images of Au-NPs endocytosed inside the cells. TEM images showing the internalization of $25 \mu \mathrm{g} / \mathrm{ml}$ Au-NPs with diameters of (A) $5 \mathrm{~nm}$, (B) $10 \mathrm{~nm}$, (C) $20 \mathrm{~nm}$ or (D) $40 \mathrm{~nm}$ into SGC-7901 cells after treatment for $24 \mathrm{~h}$. Scale bar, $200 \mathrm{~nm}$.

\section{Results}

Synthesis and characterization of Au-NPs. Au-NPs without any further modification, referred to as unmodified nanoparticles, were used in the present study. To explore the size-dependent effect of the nanoparticles, Au-NPs were synthesized in four sizes $(5,10,20$ and $40 \mathrm{~nm})$ and characterized by TEM and UV-Vis spectra (Fig. 1). The particles exhibited spherical shape and were quite uniform in size in each group (Fig. 1A-D). All samples presented a sharp and single absorption band (Fig. 1E).

Internalization of $A u-N P s$. To establish whether Au-NPs entered the cells and where they located, SGC-7901 cells were cultured in complete medium containing Au-NPs (5, 10, 20 or $40 \mathrm{~nm}$ ) for 24 h. Fig. 2 shows the internalization and distribu- 


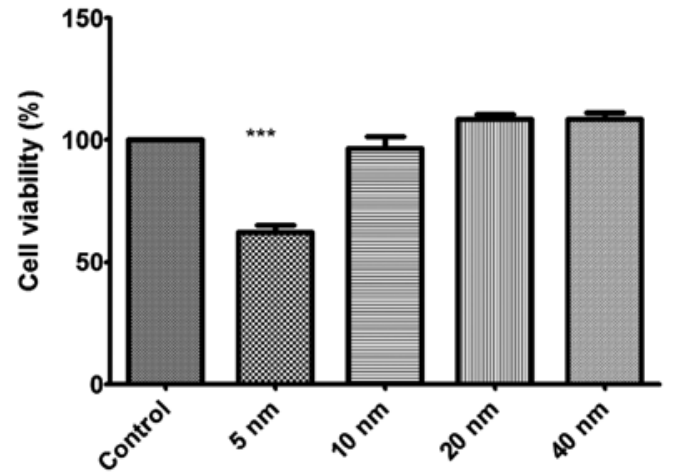

Figure 3. Comparison of the viability of SGC-7901 cells exposed to Au-NPs. Cell viability was calculated as the percentage of the viable cells compared to the untreated controls. Each result represents the mean viability \pm standard deviation (SD) of three independent experiments. ${ }^{* * *} \mathrm{P}<0.001$ vs. control.

tion of Au-NPs with various sizes in SGC-7901 cells. Most of the particles appeared in vesicles or perinuclear region within the cells.

Effect of Au-NPs on proliferation of SGC-7901 cells. Then, we sought to investigate the effect of these Au-NPs on cell viability in human gastric carcinoma SGC-7901 cells. The results showed that only 5-nm Au-NPs exhibited obvious inhibition on the proliferation of SGC-7901 cells (Fig. 3). Au-NPs 10,20 and $40 \mathrm{~nm}$ in size showed no significant effects on cell viability in SGC-7901 cells.

Invasion assay. A classic membrane model was built for determining the invasion ability of SGC-7901 cells. Fig. 4 shows that cell invasion was suppressed significantly by 5 -nm Au-NPs $(\mathrm{P}<0.05)$. While 10-, 20- or 40-nm Au-NPs showed no significant influence on invasion ability of SGC-7901 cells.

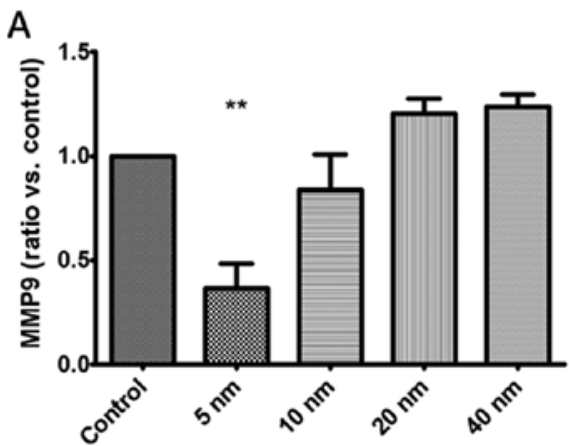

B



Figure 5. Fold changes in mRNA expression tested by qRT-PCR in SGC-7901 cells treated with differently sized nanoparticles. Results of qRT-PCR for (A) MMP9 and (B) ICAM-1 in SGC-7901 cells after 24-h incubation with 5-, 10-, 20- or 40-nm Au-NPs. ${ }^{* *} \mathrm{P}<0.01$ vs. control. Error bars indicate the SD values from three independent experiments.

These findings indicated that the effects of Au-NPs on cell invasion might be size-dependent.

Effects of Au-NPs on the expression of MMP9 and ICAM-1 in SGC-7901 cells. To obtain further understanding of the above phenomenon, qRT-PCR was carried out to evaluate the
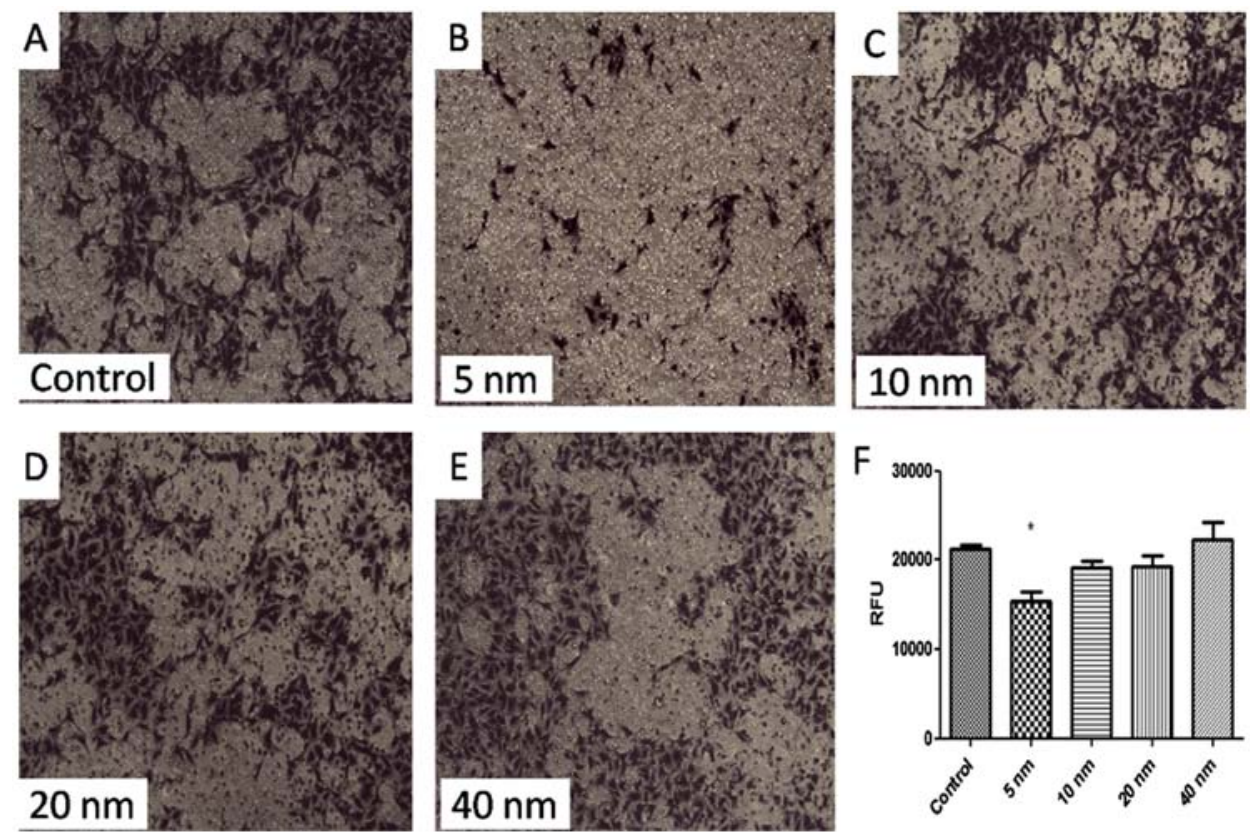

Figure 4. Optical images and fluorescence measurements of cell invasion by Au-NP treatment. The images represent SGC-7901 cells that have crossed the membrane of chamber (A-E) and corresponding fluorescence intensity results $(\mathrm{F}){ }^{*} \mathrm{P}<0.05$ vs. control. Error bars indicate the SD values from three independent experiments. 

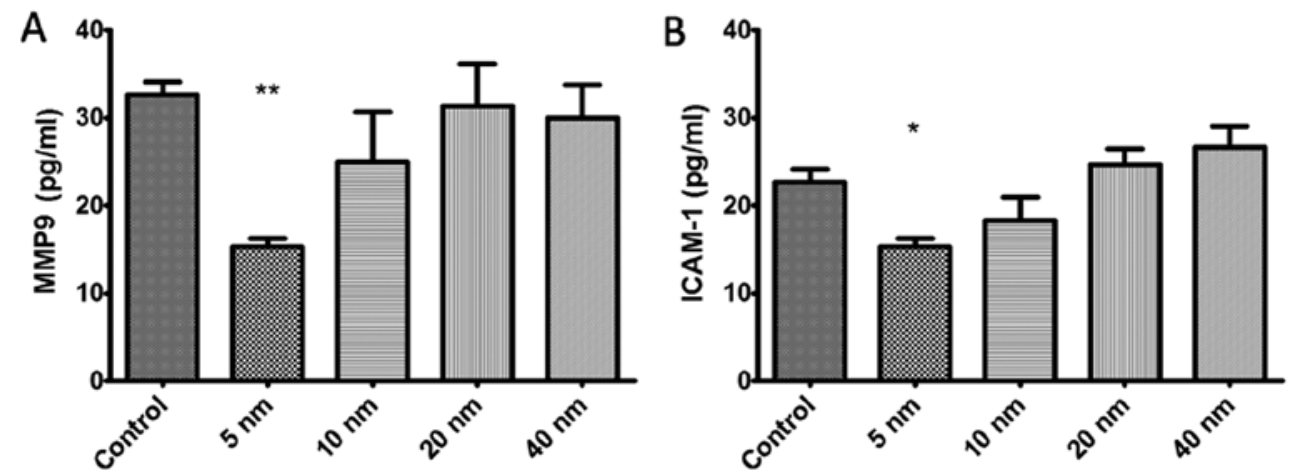

Figure 6. Expression levels of MMP9 and ICAM-1 in SGC-7901 cells after Au-NP treatment for 24 h. Quantification of the protein expression of (A) MMP9 and (B) ICAM-1 in SGC-7901 cells was conducted using the Luminex technology. ${ }^{*} \mathrm{P}<0.05,{ }^{* *} \mathrm{P}<0.01$ vs. control. Error bars indicate the SD values from three independent experiments.

mRNA expression of MMP9 and ICAM-1 after the treatment of Au-NPs. Our findings demonstrated that 5-nm Au-NPs notably reduced the mRNA expression of MMP9 and ICAM-1 in SGC-7901 cells (Fig. 5), while no significant difference were observed in 10-, 20- and 40-nm Au-NPs groups.

Furthermore, we conducted a Luminex-based experiment using MMP9/ICAM-1 magnetic beads to quantify the protein expression of MMP9 and ICAM-1 in SGC-7901 cells. Fig. 6 shows that treatment with 5-nm Au-NPs obviously decreased the protein expression of MMP9 and ICAM-1 in SGC-7901 cells $(\mathrm{P}<0.05)$, while no obvious change was found in 10-, 20 and 40-nm Au-NPs groups.

\section{Discussion}

Nanotechnology is one of the most active research fields in modern sciences. Nanotechnology has created a new world in the development of nanomedicine such as diagnostic and therapeutic applications. In this filed, Au-NPs become viable for future biomedical applications because of the low production cost and ease of synthesizing (21-23). However, more information is required on the basal biological interactions before Au-NPs transit from the laboratory to the clinic. Before Au-NPs are applied to biological systems, it is vital to demonstrate the biocompatibility of these nanoparticles. Similar to many previous reports $(24,25)$, this study also found that Au-NPs were easily endocytosed by SGC-7901 cells and localized in vesicles and the perinucleus.

We found that smaller Au-NPs $(5 \mathrm{~nm})$ inhibited cell proliferation obviously in SGC-7901 cells. While, no obvious cytotoxicity was found in 10-, 20- and 40-nm groups, which is in line with some previous research. Arvizo et al (26) showed that surface size plays a vital role in the biomedical effect of Au-NPs. While some other studies came to different conclusions. Connor et al (10) reported that AuNPs in size of 4, 12 and $18 \mathrm{~nm}$ had no acute toxicity on K562 leukemia cells, and they concluded the cytotoxicity came from cetyltrimethyl ammonium bromide (CTAB) coating of AuNPs. Cui et al (27) even found the opposite results that AuNPs promoted cell proliferation when AuNPs gathered on the cell surface instead of within the cells. Furthermore, Patra et al (28) demonstrated that AuNPs did not universally target all cell types, which may explain the controversy among the above studies.
At present, the mechanism on inhibition of cell proliferation by AuNPs is not exact. Firstly, most research considered that the generation of reactive oxygen species (ROS) was the main reason that AuNPs caused cytotoxicity $(29,30)$. Secondly, AuNPs may cause cell morphological change and cytoskeleton defects, leading to cell damage and inhibition of proliferation (28). Besides, AuNPs could also interfere in the expression level of proliferation-related genes (31).

In the present study, the inhibited invasion ability was associated by a remarkable downregulation of MMP9 and ICAM-1 expression. As known from tumor metastasis, tumor cells spread along the blood vessel or lymph-vessel after invasion through the ECM. Matrix metalloproteinase, a kind of endopeptidase, can degrade ECM components, allowing tumor cells to access the blood vessel or lymphvessel $(32,33)$. As an important matrix metalloproteinase, MMP9 is able to degrade type IV collagen, which is the basic component of the basement membrane. Some studies found that increased expression of MMP9 in patients with gastric cancer was correlated with a greater risk of advanced cancers $(34,35)$; therefore, drugs restraining the expression of the MMPs could suppress tumor cell metastasis. Also, ICAM-1 is a pivotal adhesion molecule affecting ECM (36). High expression of ICAM-1 in human gastric cancer has been reported (37). Rosette et al (38) found that downregulation of ICAM-1 mRNA or protein caused strong inhibition of human breast cell invasion. In this study, 5-nm Au-NPs effectively suppressed the expression of MMP9 and ICAM-1 in SGC-7901 cells, which might explain the weakened effect of the nanoparticles on tumor cell invasion. The downregulation effects of Au-NPs on MMP9 and ICAM-1 expression in SGC-7901 cells indicated that small nanoparticles might possess the ability to suppress the invasion of gastric cancer cells, while further studies in vivo are needed to confirm the mechanisms.

To the best of our knowledge, this is the first evidence for the effect of gold nanoparticles on gastric cancer cell proliferation and invasion in vitro, which would make a great contribution to the application of Au-NPs to novel therapies in gastric cancer. Our research suggested that the biomedical effects of unmodified Au-NPs depended largely on the particle size. There are opportunities in developing Au-NPs to possess intrinsic therapeutic potential for clinical application. 
In conclusion, the present study provides new evidence of unmodified Au-NPs of different sizes on the proliferation and invasion in gastric cancer cells. Particle size is an essential factor to their biomedical effects. Only 5-nm Au-NPs inhibited proliferation and invasion in SGC-7901 cell, and the decreased invasion activity may be attributed to the downregulation of MMP9 and ICAM-1 expression. This study provides useful information on the effects of Au-NPs on cell proliferation and invasion, which could make a great contribution to the application of $\mathrm{Au}-\mathrm{NPs}$ to novel therapies in gastric cancer.

\section{Acknowledgements}

We thank all the participants in the present study.

\section{References}

1. Arvizo RR, Bhattacharyya S, Kudgus RA, Giri K, Bhattacharya R and Mukherjee P: Intrinsic therapeutic applications of noble metal nanoparticles: Past, present and future. Chem Soc Rev 41: 2943-2970, 2012.

2. Dreaden EC, Alkilany AM, Huang X, Murphy CJ and El-Sayed MA: The golden age: Gold nanoparticles for biomedicine. Chem Soc Rev 41: 2740-2779, 2012.

3. Dykman LA and Khlebtsov NG: Gold nanoparticles in biology and medicine: Recent advances and prospects. Acta Naturae 3 : $34-55,2011$.

4. Huang X, Jain PK, El-Sayed IH and El-Sayed MA: Gold nanoparticles: Interesting optical properties and recent applications in cancer diagnostics and therapy. Nanomedicine (Lond) 2: 681-693, 2007.

5. Giljohann DA, Seferos DS, Daniel WL, Massich MD, Patel PC and Mirkin CA: Gold nanoparticles for biology and medicine. Angew Chem Int Ed Engl 49: 3280-3294, 2010.

6. Dreaden EC, Mackey MA, Huang X, Kang B and El-Sayed MA: Beating cancer in multiple ways using nanogold. Chem Soc Rev 40: 3391-3404, 2011.

7. Arvizo RR, Saha S, Wang E, Robertson JD, Bhattacharya R and Mukherjee P: Inhibition of tumor growth and metastasis by a self-therapeutic nanoparticle. Proc Natl Acad Sci USA 110: 6700-6705, 2013.

8. Arvizo RR, Rana S, Miranda OR, Bhattacharya R, Rotello VM and Mukherjee P: Mechanism of anti-angiogenic property of gold nanoparticles: Role of nanoparticle size and surface charge. Nanomedicine 7: 580-587, 2011.

9. Alkilany AM and Murphy CJ: Toxicity and cellular uptake of gold nanoparticles: What we have learned so far? J Nanopart Res 12: 2313-2333, 2010.

10. Connor EE, Mwamuka J, Gole A, Murphy CJ and Wyatt MD: Gold nanoparticles are taken up by human cells but do not cause acute cytotoxicity. Small 1: 325-327, 2005.

11. Eccles SA, Box C and Court W: Cell migration/invasion assays and their application in cancer drug discovery. Biotechnol Annu Rev 11: 391-421, 2005.

12. Ju D, Sun D, Xiu L, Meng X, Zhang C and Wei P: Interleukin-8 is associated with adhesion, migration and invasion in human gastric cancer SCG-7901 cells. Med Oncol 29: 91-99, 2012.

13. Busch J, Stephan C, Klutzny A, Hinz S, Kempkensteffen C, Kilic E, Lein M, Weikert S, Miller K and Magheli A: Impact of positive surgical margins on oncological outcome following laparoscopic radical prostatectomy (LRP): long-term results. World J Urol 31: 395-401, 2013.

14. Dassen AE, Dikken JL, van de Velde CJ, Wouters MW, Bosscha K and Lemmens VE: Changes in treatment patterns and their influence on long-term survival in patients with stages I-III gastric cancer in The Netherlands. Int J Cancer 133: 1859-1866, 2013.

15. Li Y, Tan BB, Zhao Q, Fan LQ, Wang D and Liu Y: ZNF139 promotes tumor metastasis by increasing migration and invasion in human gastric cancer cells. Neoplasma 61: 291-298, 2014.

16. Manu KA, Shanmugam MK, Ramachandran L, Li F, Fong CW, Kumar AP, Tan P and Sethi G: First evidence that $\gamma$-tocotrienol inhibits the growth of human gastric cancer and chemosensitizes it to capecitabine in a xenograft mouse model through the modulation of NF-kB pathway. Clin Cancer Res 18: 2220-2229, 2012.
17. Chen P, Zhao D, Sun Y, Huang L, Zhang S and Yuan Y: Protein inhibitor of activated STAT-1 is downregulated in gastric cancer tissue and involved in cell metastasis. Oncol Rep 28: 2149-2155, 2012.

18. Jiang Z, Guo J, Xiao B, Miao Y, Huang R, Li D and Zhang Y: Increased expression of miR-421 in human gastric carcinoma and its clinical association. J Gastroenterol 45: 17-23, 2010.

19. Slot JW and Geuze HJ: A new method of preparing gold probes for multiple-labeling cytochemistry. Eur J Cell Biol 38: 87-93, 1985.

20. Frens G: Controlled nucleation for the regulation of the particle size in monodisperse gold suspensions. Nature 241: 20-22, 1973.

21. Khlebtsov N and Dykman L: Biodistribution and toxicity of engineered gold nanoparticles: A review of in vitro and in vivo studies. Chem Soc Rev 40: 1647-1671, 2011.

22. Mesbahi A: A review on gold nanoparticles radiosensitization effect in radiation therapy of cancer. Rep Pract Oncol Radiother 15: 176-180, 2010.

23. Lévy R, Shaheen U, Cesbron Y and Sée V: Gold nanoparticles delivery in mammalian live cells: A critical review. Nano Rev 1: $1,2010$.

24. Coulter JA, Jain S, Butterworth KT, Taggart LE, Dickson GR, McMahon SJ, Hyland WB, Muir MF, Trainor C, Hounsell AR, et al: Cell type-dependent uptake, localization, and cytotoxicity of $1.9 \mathrm{~nm}$ gold nanoparticles. Int J Nanomed 7: 2673-2685, 2012.

25. Tsai SW, Liaw JW, Kao YC, Huang MY, Lee CY, Rau LR, Huang CY, Wei KC and Ye TC: Internalized gold nanoparticles do not affect the osteogenesis and apoptosis of MG63 osteoblastlike cells: A quantitative, in vitro study. PLoS One 8: e76545, 2013.

26. Arvizo R, Bhattacharya R and Mukherjee P: Gold nanoparticles: Opportunities and challenges in nanomedicine. Expert Opin Drug Deliv 7: 753-763, 2010.

27. Cui W, Li J, Zhang Y, Rong H, Lu W and Jiang L: Effects of aggregation and the surface properties of gold nanoparticles on cytotoxicity and cell growth. Nanomedicine 8: 46-53, 2012.

28. Patra HK, Banerjee S, Chaudhuri U, Lahiri P and Dasgupta AK: Cell selective response to gold nanoparticles. Nanomedicine 3: 111-119, 2007.

29. Thakor AS, Paulmurugan R, Kempen P, Zavaleta C, Sinclair R, Massoud TF and Gambhir SS: Oxidative stress mediates the effects of Raman-active gold nanoparticles in human cells. Small 7: 126-136, 2011

30. Pan Y, Leifert A, Ruau D, Neuss S, Bornemann J, Schmid G, Brandau W, Simon U and Jahnen-Dechent W: Gold nanoparticles of diameter $1.4 \mathrm{~nm}$ trigger necrosis by oxidative stress and mitochondrial damage. Small 5: 2067-2076, 2009.

31. Yang Y, Qu Y and Lü X: Global gene expression analysis of the effects of gold nanoparticles on human dermal fibroblasts. J Biomed Nanotechnol 6: 234-246, 2010.

32. Hamano Y, Zeisberg M, Sugimoto H, Lively JC, Maeshima Y, Yang C, Hynes RO, Werb Z, Sudhakar A and Kalluri R: Physiological levels of tumstatin, a fragment of collagen IV alpha3 chain, are generated by MMP-9 proteolysis and suppress angiogenesis via alphaV beta3 integrin. Cancer Cell 3: 589-601, 2003.

33. Egeblad M and Werb Z: New functions for the matrix metalloproteinases in cancer progression. Nat Rev Cancer 2: 161-174, 2002.

34. Fanelli MF, Chinen LT, Begnami MD, Costa WL Jr, Fregnami JH, Soares FA and Montagnini AL: The influence of transforming growth factor- $\alpha$, cyclooxygenase- 2 , matrix metalloproteinase (MMP)-7, MMP-9 and CXCR4 proteins involved in epithelialmesenchymal transition on overall survival of patients with gastric cancer. Histopathology 61: 153-161, 2012.

35. Mroczko B, Groblewska M, Łukaszewicz-Zajac M, Bandurski R, Kedra B and Szmitkowski M: Pre-treatment serum and plasma levels of matrix metalloproteinase 9 (MMP-9) and tissue inhibitor of matrix metalloproteinases 1 (TIMP-1) in gastric cancer patients. Clin Chem Lab Med 47: 1133-1139, 2009.

36. Hanahan D and Weinberg RA: Hallmarks of cancer: The next generation. Cell 144: 646-674, 2011.

37. Sunami T, Yashiro M and Chung KH: ICAM-1 (intercellular adhesion molecule-1) gene transfection inhibits lymph node metastasis by human gastric cancer cells. Jpn J Cancer Res 91: 925-933, 2000.

38. Rosette C, Roth RB, Oeth P, Braun A, Kammerer S, Ekblom J and Denissenko MF: Role of ICAM1 in invasion of human breast cancer cells. Carcinogenesis 26: 943-950, 2005. 